\title{
El carácter intrínsecamente teatral del mito fáustico
}

\author{
Carmen Leñero
}

Mucho se ha escrito sobre las diferencias (históricas, ideológicas, filosóficas, políticas, estéticas) entre los diversos personajes ficticios que han encarnado el mito fáustico. La figura de Fausto ha atravesado la historia moderna desde sus inicios hasta el día de hoy: desde principios del renacimiento, pasando por la ilustración, el romanticismo y existencialismo del siglo xx, y ha "transmigrado" de un género artístico a otro: de la leyenda oral al teatro, del poema a la novela, del ensayo a la pintura o la música, del tablado de títeres a la ópera y el cine. En cada uno de estos ámbitos de ficción, su famoso pacto con el Mal (materializado en otra figura clave del mito: el Diablo) cambia de significación, ya sea que se conciba a Fausto como representante de la cultura alemana en particular, de la cultura europea y occidental en general, o incluso del género humano. Sin ignorar los contextos culturales de las obras en que aparece, en este ensayo exploro los aspectos propiamente "teatrales", comunes a todas las versiones del mito. Me referiré en especial al Volksbuch o Libro popular del Doctor Faustus, editado por Johann Spies en 1587, a la pieza teatral de Christopher Marlowe (1592), a El drama de títeres, cuya primera representación data de 1746, a las dos partes el poema dramático Fausto de Johann W. von Goethe (de 1808 y de 1832, respectivamente) y a la novela de Thomas Mann, Doctor Faustus (1947).

Palabras clave: Fausto, Mefistófeles, Marlowe, Goethe, Mann, teatralidad.

Much has been written about the historical, ideological, philosophical, politi$\mathrm{cal}$, and aesthetic differences between the fictional characters embodying the Faust Myth. The image of Faust has passed throughout modern history right up to the present day: from the Renaissance, through the Enlightenment, to twentieth-century Romanticism and Existentialism. It has also "transmigrated" 
from one artistic genre to another: from oral legend to theatre; from poetry to novelistic writing; from essay to painting and music composition; and from puppet theatre to opera and film. Within each of these spheres, the meaning of Faust's famous pact with Evil (represented by another key figure, The Devil) takes on a new significance, depending on whether one conceives of Faust as a representation of Germanic culture in particular, of European or occidental culture in general, or as a personification of the universal human condition. Without ignoring the cultural contexts of the works in which he appears, this essay explores the theatrical aspects shared by every version of the myth. I will address principally the Volksbuch, edited by Johann Spies in 1587; the play written by Christopher Marlowe (1604); The Puppet Play (first staged in 1746); the two parts of Johann von Goethe's dramatic poem, Faust (1808 and 1832); and the novel by Thomas Mann, Doctor Faustus (1947).

KEYwords: Faust, Mephistopheles, Marlowe, Goethe, Mann, theatricality.

Fecha de recepción: 23 de noviembre de 2012

Fecha de aceptación: 14 de mayo de 2013 


\author{
Carmen Leñero \\ Universidad Nacional Autónoma de México \\ Instituto de Investigaciones Filológicas
}

\title{
El carácter intrínsecamente teatral del mito fáustico ${ }^{1}$
}

\section{El mal invisible}

Mientras mirábamos la imagen de la Hidra en un grabado de Doré mi padre aseguró, seguramente para tranquilizarme, que la maldad y su "Príncipe", el Diablo, no tenían existencia por sí mismos. Y, siguiendo al ex maniqueo san Agustín, me recitó que el Mal era sólo la falta del Bien, es decir, su ausencia. ¿Pero por qué "una ausencia” tiene nombre, imagen, cuerpo?, repliqué. Ah, respondió, porque el nombre, o más bien dicho, los muchos nombres del Diablo: Satán, Luzbel, Belcebú, Lucifer, así como su imagen de ángel caído, de serpiente, de macho cabrío o de monstruo marino son sólo "representaciones", maneras de simbolizar la negación de lo bueno. ¿Entonces, pregunté — no sé si en voz alta o para mis adentros-, Dios es también un símbolo de "lo bueno"? No, Dios es un ser real, porque además de haber creado el mundo, se nos reveló en la Historia como un hombre de carne y hueso: Jesucristo... ¿Y el Diablo no se encarna también en hombres malvados? No, concluyó rotundo mi padre, porque el Diablo no existe.

\footnotetext{
${ }^{1}$ Este artículo es un fragmento de un trabajo mayor titulado: Las transmigraciones de Fausto, en el que estudio las distintas características estéticas que su figura adquiere en tanto que personaje de una imaginación teatral, poética o novelesca.
} 
Pero resulta que un día, aquello que no existe surgió ante mis ojos en un portentoso escenario. Mi padre me llevó por primera vez al Palacio de Bellas Artes a ver la ópera Fausto, de Gounod. Yo tenía apenas seis años. Cuando se abrió el telón vi una escena que nunca olvidaré: en un amplio y oscuro gabinete, un barbado Doctor Fausto (sabio, mago y científico - me susurró mi padre al oído-), rodeado de libros, enigmáticos aparatos e instrumentos de alquimia, cantaba a solas pero a voz en cuello; todo ello tras un telón translúcido que como un velo daba al espacio escénico el carácter de una visión fantástica. Por una de las esquinas del foro se asomó, iluminado por un reflector, el "inexistente" personaje diabólico, Mefistófeles, con su ondeante capa roja. Su aparición me quitó el aliento, y sus acrobacias por el escenario, así como su envolvente voz de bajo profundo, me mantuvieron hechizada toda la obra. No es de sorprender que Fausto se dejará engatusar por aquel personaje fascinante (el "Tentador" — volvió a murmurar mi padre-), ni que mi admiración inicial por la noble figura del sabio nigromante se fuera desvaneciendo al conocer sus desquiciados deseos, su temeridad para vender el alma al mismísimo Satán, su falta de previsión, y en fin, su inexplicable ingenuidad.

\section{El Diablo se apersona}

Tal vez el diablo "no existe", pero bien que negociamos con él cuando queremos averiguarlo todo y obtener cosas imposibles, como vencer a la muerte, ser famosos o crear una obra de arte extraordinaria, aprendí a pensar con los años. Pero para "negociar" con alguien hay que hablarle, verle a la cara, oír su voz, sus argumentos, tenerlo enfrente. Ya sea que no exista o que sólo se trate de una fuerza espiritual, psíquica o metafísica, el prodigio de que dicha "fuerza" adquiera un cuerpo, una voz y se haga presente, tangible, visible, audible, es prerrogativa de lo teatral. El mito fáustico implica no sólo el rito de invocación al Diablo, sino su aparición objetiva — cumpliendo así la función primordial de lo teatral: "traer a la presencia" a los fantasmas y espectros, a los dioses invisibles o a los muertos, para que dialoguen 
con los vivos- ${ }^{2}$ Mediante la ficción escénica, que encarna y actualiza "lo oculto", "lo ausente", dicho encuentro se hace posible, gracias en buena parte a los testigos oculares (los espectadores) que asisten al acontecimiento y lo "miran" ocurrir, convirtiéndolo precisamente en una "escena".

La trágica historia del doctor Fausto, escrita en 1592 por Christopher Marlowe - cuyo programa estético era "alzar el espejo del teatro a la altura de aspectos de la experiencia jamás representados" - 3 pone ante nuestros ojos fuerzas invisibles, corporeizadas. Si Marlowe decidió retomar la leyenda oral recogida en The English Book of Faust — traducción del Volksbuch germano — ${ }^{4}$ para escribir una de sus piezas teatrales, tan "pródigas en efectos atroces y fastuosos", es quizá porque reconoció no sólo las virtudes "espectaculares" de la historia de Fausto, sino el núcleo dramático (trágico, en el sentido griego) de aquella fábula moral, uno de cuyos ingredientes era sin duda la personificación del Mal en una figura corpórea y actuante: Mefistófeles - ya no como la simple imagen alegórica del demonio, lo cual era habitual en los $\mathrm{Mi}$ lagros y otras representaciones medievales, sino como un personaje complejo, paradójico y "verosímil"- Es a partir de ese "ingrediente" que la imaginación del dramaturgo se dispara. Y en efecto, las primeras representaciones de La trágica historia del doctor Fausto, realizadas por la compañía de teatro "The Admiral's Men" tuvieron "un poderoso efecto en el público y levantaban polémica", cuenta un reseñista de la época, William Pryne, en su Histriomastix de 1632. En dichas puestas en escena se vivía, dice, "el pánico de una verdadera presencia demoníaca", al punto de que en ocasiones "algunas personas de público enloquecieron al ver al verdadero diablo apareciendo en escena, para sorpresa de actores y espectadores" (apud Marcelo Cohen, "Introduc-

${ }^{2}$ Cfr. Carmen Leñero, "Poética y teatralidad", La escena invisible, 21-32.

${ }^{3}$ Cfr. Prólogo de Marlowe a la primera parte de Tamerlán el Grande (citado por Marcelo Cohen, "Introducción”, La trágica historia del doctor Fausto, 29).

${ }^{4}$ El Volksbuch o Libro popular del doctor Faustus, primera obra impresa de la leyenda, editada por Johann Spies en Frankfurt, en 1587, reúne una serie de relatos orales sobre la figura legendaria de un tal George Sabellicus o Johann Fausten (que vivió alrededor del 1500, contemporáneo a Lutero y a Paracelso), en la que se condensan muchos personajes nigromantes-científicos que vivieron en Europa durante la transición entre el Medievo y el Renacimiento. 
ción”, La trágica historia del doctor Fausto, 34). Así, gracias a su teatralización formal, la leyenda de Fausto recupera la forma original que muy probablemente le dio vida en la imaginación del pueblo: aquella escena donde el Mal se materializa para convertirse en una experiencia sensible y actual que invade la realidad cotidiana de los hombres, más allá de cualquier fantasía o delirio.

Mefistófeles - mensajero y representante del Diablo—, quien cambia de forma y disfraz igual que un actor, es incluso capaz de salirse del espacio de ficción, traspasar los límites del escenario e invadir el terreno de la realidad (la de los espectadores). Ello ocurre, por ejemplo, en el acto tercero de la segunda parte del Fausto de Goethe, cuando "Forkias", 5 monstruo femenino preolímpico de un solo ojo y un solo diente, se quita la máscara y, dirigiéndose al público, muestra que se trata en realidad de Mefistófeles. Al llegar a esta escena, aun cuando uno se encuentre sólo leyendo la obra, es imposible no sentir un oscuro estremecimiento.

Goethe, quien concibe lo demoníaco como una fuerza aterradora y contradictoria (Misterium tremens y Misterium numinosum), ${ }^{6}$ que no puede nombrarse con palabras ni comprenderse con la razón y de la que hay que salvarse mediante la creación de una imagen viva, materializa en la figura de Mefistófeles una de las máscaras de "El Maligno". Se trata de un personaje que a su vez se enmascara de otros personajes y puede transfigurarse de manera continua, trastornando consigo el tiempo y el espacio del hombre, pervirtiéndolo. "Soy el que niega", dice el Mefistófeles de Goethe; "el Otro", le había llamado Marlowe, convirtiéndolo así en el antagonista por excelencia. En el Doctor Faustus de Mann nos encontramos con un demonio secularizado, ya fuera

\footnotetext{
${ }^{5}$ Forkias es una figura maléfica de la mitología griega, que en el poema de Goethe orquesta todo el episodio "ilusionista" que corresponde a la relación entre el fantasma de Helena y Fausto (cfr. Fausto, 331-378).

${ }^{6}$ Lo demoníaco, dice Goethe en Poesía y verdad, es aquella "fuerza de la naturaleza, tanto animada como inanimada, algo que sólo se manifestaba en forma de contradicciones, semejante al azar o a la Providencia"; una fuerza que se complace en lo imposible - y desprecia lo posible - y juega a capricho con nuestra existencia, "encogiendo el tiempo y estirando el espacio" (apud González García, Las huellas de Fausto, 147). Esta fuerza contradictoria se individualiza en el daimon: genio, sombra o demonio que, actuando desde el interior secreto del sujeto, determina su destino.
} 
del contexto religioso cristiano, pero que sigue siendo "El que niega", "El adversario", "El hijo del caos", "El impostor", y cuya figura perturbadora se difracta también en varios personajes. Su aparición positiva en el centro de la novela, ya sea como personaje "real" o bien como o proyección mental de Adrián Leverkühn (a su vez máscara y reencarnación moderna de Fausto) durante el episodio que Mann llama: "Conversación con el demonio", instaura una auténtica escena teatral. El impacto que produce esta "escena" ha sido preparado, anticipado y reforzado por el narrador de la novela: Zeitblom, cuya mirada, en su función de testigo ocular y biógrafo, coloca al lector también en la posición de un espectador presente, sobrecogido. ${ }^{8}$ Pero claro, Thomas Mann estaba escribiendo una novela moderna y realista, en la que todo elemento fantástico no podía presentarse sino como alucinación de alguno de los personajes. Así que, ante el peligro de provocar un efecto demasiado "materializado" del Diablo, según confiesa en Los orígenes del doctor Fausto, el novelista se propuso "presentar al demonio con tres máscaras [...] siempre envuelto en glacial frialdad" (67): la de un strizzi afeminado, la de un caballero noble e intelectual y la de un hombre de "bigotito retorcido". Además, el novelista hace que durante todo este "episodio dialogado", transcrito por el propio Leverkühn —en la posición de actor y espectador a un tiempo-, el protagonista ("Yo") no deje de insistir en que el apersonamiento del Diablo ("Él") no puede ser "objetivo", sino sólo fruto de su mente trastornada. "Ten un poco de orgullo, le replica el Diablo, y no recuses el testimonio de tus cinco sentidos" (Doctor Faustus, 274). El lector, en su cinco sentidos "asiste" entonces a la siguiente parte de la conversación:

YO: ...cada tres palabras que usted pronuncia, demuestra su inexistencia. Dice cosas que están en mí y vienen de mí, no de usted...

\footnotetext{
${ }^{7}$ Escena constituida por una serie de parlamentos entre "Él" y "Yo", incluso con didascalias formales, registrado por Adrián en una carta. Ocurre justo a mitad de la novela y constituye el largo capítulo xxv (Doctor Faustus, 269-307). "En este capítulo, advierte Zeitblom, el lector oirá la propia voz de Adrián" (270).

${ }^{8}$ En efecto, para pasar del ámbito "teatral" del diálogo con el demonio al terreno novelesco, Mann se vale de dos mediaciones: primero, la carta de Adrián que relata la escena que vivió, y luego la transcripción que hace Zeitblom. La verosimilitud en cuanto a la personificación del Diablo queda, pues, doblemente velada.
} 
ÉL: (con sonrisa afectada, divertido) ...harías mejor en deducir que no solamente soy de carne y hueso, sino también el mismo por quien tú me tienes $[\ldots]$ No finjas ahora, que me has estado esperando durante largo tiempo [...] ¿Cómo me llamo? Vamos a ver; tú tienes presentes todos los apodos triviales $[\ldots]$ que provienen de mi popularidad tan germánica"

[...] "Yo hago lo que digo y cumplo mi palabra en sus más insignificantes pormenores; ése es precisamente mi principio comercial" (275276).

En efecto, es lo inexorable y puntual de su "actuación" lo que va dejando sentir la presencia del Demonio conforme trascurre la narración de Zeitblom. Así, incluso antes y después de que se presente directamente ante Leverkühn, el Diablo ronda los distintos capítulos de la novela a modo de anticipación, inminencia o caricatura, y se prefigura en personajes de los cuales el lector, que conoce de antemano el mito fáustico, sospecha sin remedio, acicateado por las falsas pistas que aporta Zeitblom. Al igual que los antiguos espectadores de la tragedia griega, quien lee la novela conoce ya el mito que la nutre y sabe básicamente cuál será el rumbo de la acción, pero está esperando constatar, con "sus propios ojos", la aparición del Diablo y corroborar su perturbadora irrupción en el entorno. ${ }^{9}$ Hay ciertos personajes que insinúan la presencia "disfrazada" de Lucifer: personajes menores como el fámulo que lleva a Leverkühn al burdel o como aquel guía de forasteros con quien se topa en la calle, encuentro que Adrián mismo describe como "lo que sucedió entre Satán y yo" (171); o personajes claves en la vida del protagonista — amigos, profesores y colegas-, cuyas ideas sugieren la influencia subterránea de "El Maligno". ${ }^{10}$ Todos ellos, al igual

${ }^{9}$ Eric Bentley explica que el suspenso del teatro no está basado en el desconocimiento de lo que va a pasar sino en la intensidad que se resiente cuando lo esperado ocurre (cfr. "Trama", en La vida del drama, 15-41). Así, al inicio de la obra de Marlowe (La trágica historia ..., 45) el coro resume la trama entera y el desenlace.

${ }^{10}$ Por ejemplo, Kumpf (profesor de Teología, personaje truculento, que tenía "un trato muy familiar con el Diablo") o el doctor Schelppfuss (demonólogo, elocuente e irónico, que poseía la habilidad de desaparecer de improviso) o Schildknapp (camarada de Adrián que, como el tradicional Mefistófeles, acompaña al protagonista durante buena parte de su vida) o Fitelberg (agente de artistas y parodia del Diablo por cuanto que intenta "comprar" al compositor). 
que Leverkühn, son recreaciones de personas "reales" de la política y la sociedad de entonces, en quienes lo demoníaco se manifiesta de algún modo. Si bien el diablo es corpóreo e incorpóreo, dice Goethe en Poesía $y$ verdad, resulta más terrible cuando encarna en hombres reales. De ellos "irradia una fuerza enorme y ejercen poder increíble sobre todas las criaturas e incluso sobre los elementos [...] la masa siéntese atraída a ellos [...] nadie puede vencerlos sino el propio universo" (apud González García, Las huellas de Fausto, 149-150). Este carisma fatal, no exento de grandeza y locura, es el mismo que Mann atribuye a Hitler, cuya "genialidad política" se torna diabólica. Pero lo demoniaco se emparenta también con la genialidad intelectual y artística de personajes como Nietzsche o Schöenberg, ambos representantes del "espíritu alemán", que transmutan, bajo la máscara mítica de Fausto, en Adrián Leverkühn.

\section{Los disfraces del Diablo, director de escena}

Consustancial a este carisma es aquello que vuelve al Diablo tan peligroso: su condición de simulador - al grado de que cualquier persona podría ser sólo una máscara del "Gran Impostor"- - Cuando el Diablo se hace presente en la dimensión humana, en la Historia y el mundo real (del que el escenario teatral es un espejo) suele transformarse de continuo no sólo en ser humano sino en cualquier otro tipo de criatura o sustancia, creando el caos y un estado de inminente desastre. Tal capacidad de metamorfosis lo define como una figura esencialmente teatral sea cual fuere el género de ficción en que aparezca. Su "invisibilidad" de "espíritu" es suplantada por una forma material visible y parlante. Sin embargo, el Diablo mismo no conoce su propia apariencia, según dice el protagonista de Mann, porque ésta es inasible "como el humo", como la "impúdica espuma"; a lo que el Diablo añade: "Mi apariencia de hoy es debida a la casualidad [...] La adaptación, el mimetismo, ya conoces todo eso ¿no es cierto? La mascarada y el juego mistificador..." (Doctor Faustus, 279). El Diablo tiene, pues, la astucia de adaptarse a su interlocutor y a cualquier circunstancia; de ahí su "efectividad" mundana - y también su naturaleza paródica—. Su condición de figura dis- 
frazada se da ya en las tempranas versiones de la leyenda recogidas en El libro popular, y se despliega en las posteriores versiones del teatro de marionetas. Así, en El drama de títeres del doctor Fausto, ${ }^{11}$ Mefistófeles dice: "Sábete, Fausto, que como gran príncipe del infierno tengo el poder de aparecer en cualquier figura que me plazca" (El libro popular..., 183); y en efecto, después de haber adoptado la figura humana, tomará la forma de "Furia" - monstruo del averno que persigue a los mortales- Como mensajero del Diablo, Mefistófeles es esencialmente una "máscara", es el actor que representa al "Maligno" en el escenario del mundo. Sus múltiples metamorfosis hacen que aún corporeizado resulte inasible. Una vez que se ha aparecido visualmente en la obra de Marlowe (en la que se disfraza de fraile franciscano, de cardenal y del propio Fausto), Mefistófeles estará siempre presente aunque se halle invisible, casi como una turbia atmósfera emocional - la misma, por cierto, que genera el narrador Zeitblom en torno a los hechos que se relatan en el Doctor Faustus - Goethe, por su parte, presenta al Diablo como un perro, como humo, como un viejo decrépito, como un estudiante, para luego transfigurarlo en un monstruo mítico de otras épocas — evidenciando así su vigencia transhistórica y transcultural—. Ya en el "mundo exterior", es decir, fuera del ámbito subjetivo del gabinete de Fausto, Goethe disfraza al Diablo de bufón y lo hace presentarse a sí mismo ante la Corte Imperial mediante una serie de adivinanzas: "¿Qué es lo que siempre maldicen y a la vez siempre reciben bien? [...] ¿Qué es lo que jamás se invoca, pero gusta nombrarlo? ¿Qué es lo que se acerca a las gradas del trono? ¿Qué se desterró a sí mismo?” (Fausto, 215). Luzbel es el ángel caído, expulsado del Cielo; pero a diferencia del Dios revelado, cuyo "reino no es de este mundo", es precisamente este mundo su lugar de exilio, su nuevo "reino": el universo alterno de las apariencias. Ahí, mediante sus artes mágicas, desvía, invierte y trastoca las leyes naturales o civiles, para orquestar una realidad corrompida. Tiene como cómplice a los hombres, o más bien dicho, a la imaginación de los hombres: esa manía de ir más allá del presente, de

${ }^{11}$ Reconstrucción de los germanistas Hamm, Schade y Engel, siguiendo la de Karl Simrock, (Insel-Verlag, 1912) de las variadas versiones populares de marionetas, que basadas en la obra de Marlowe, El libro popular, las compañías ambulantes llevaron por Europa durante los siglos XVII, XVIII y XIX. 
reconstruir a capricho el pasado y de soñar con bienes imperecederos. El Diablo sólo necesita suplantar la Realidad con ese mundo ilusorio que su presencia instaura. Por eso el arte, creador de ficciones, es uno de sus ámbitos de acción favoritos: hace poesía pervirtiendo el lenguaje; hace teatro pervirtiendo la materia o el tiempo; hace novela pervirtiendo la memoria y filosofa riendo. Cuando bajo la figura de Forkias ha terminado de "suscitar" los eventos amorosos entre Helena y Fausto, el Diablo se desenmascara en proscenio, mostrándose ante espectadores y lectores no sólo como El Gran Simulador sino como un auténtico director de escena, responsable del espectáculo (378) Su sola aparición provoca en el "Teatro del mundo" un orden fantasmagórico. En efecto, el Diablo trastorna el universo de los hombres, "encogiendo el tiempo y estirando el espacio", ${ }^{12}$ dice Goethe, para crear sólo una imagen alterna de la realidad — tal como lo hace la ficción teatral, por cierto- . El primer destinatario del espectáculo es el propio Fausto, fascinado espectador que quiere conocer "en vivo" y con sus propios ojos los secretos del cosmos. En la tragedia de Marlowe, por ejemplo, vemos cómo Lucifer y Belcebú presentan ante Fausto el desfile de los Siete Pecados Capitales, y luego, viajando sobre un Dragón volador, Mefistófeles le muestra el mundo desde arriba. En el poema de Goethe, la secuencia carnavalesca y siniestra de la Noche de Walpurgis - preludio del infierno-, donde el mundo da vueltas y las brujas cantan, constituye también una clara puesta en escena por parte de Diablo. ${ }^{13}$ Para satisfacer su anhelo de vivir todas las experiencias humanas y expandir su yo al máximo, Fausto obtiene de Mefistófeles, además, la oportunidad de participar en forma directa en la fantasmagoría mundana, transformándose él mismo en un simulador: "Pero ahora, para que el orgulloso Papa se rinda ante la astucia de Juan Fausto, concédeme ser actor de este espectáculo" ( $\mathrm{La}$ trágica historia..., 78), dice el Fausto de Marlowe, al llegar a Roma, donde Mefistófeles le concederá también el don de la invisibilidad (83). En el texto de Goethe es el diabólico director escénico quien en varios momentos dicta a Fausto sus parlamentos: "Espero desde aquí captarme

${ }^{12}$ Véase nota 5.

${ }^{13}$ Mefistófeles, Fausto y el "Fuego fatuo" cantan bajo una luna roja: "Estamos según parece, dentro de una atmósfera de sueño y magia [...] todo da vueltas a nuestro alrededor..." (Fausto, 179-180). 
el favor del público; la oratoria del Diablo consiste en apuntar" (Fausto, 266), murmura en un "aparte", interpelando en realidad al público del teatro - o al lector del poema- . Asimismo, el Diablo comparte con Fausto su magia y lo habilita como creador de ficciones, para que pueda, por ejemplo, "enfurecer al Papa exponiendo tus poderes o hacer añicos su soberbia, transformar en monos a los abades y a los monjes para que se mofen de su triple corona, maniatar a los frailes con sus propios rosarios o hacer que nazcan cuernos a los cardenales", según dice "El Tentador" en la pieza de Marlowe (La trágica historia ..., 179). Gracias a esa facultad de ilusionista, Fausto hace aparecer los espectros de Alejandro Magno, de Darío y de Helena, generando auténticas escenas fantásticas ante los demás personajes: el Papa, el Emperador, la Duquesa, o la gente de la corte - representantes del mundo real de entonces-, y en segunda instancia, ante el público que mira desde las butacas. Dichas escenas constituyen un verdadero "teatro dentro del teatro" y a menudo conllevan un giro paródico en la acción dramática. ${ }^{14}$ Ejemplo claro de este recurso meta-teatral es la secuencia que se desarrolla en la segunda parte del texto de Goethe, cuando en la Sala de los caballeros, frente al Emperador y su corte, el Astrólogo (personaje que también "representa” simultáneamente a Fausto el Nigromante y al Diablo Escenógrafo) anuncia el comienzo de la función:

Nuestro señor ordena que comience el drama inmediatamente. ¡Paredes abríos! Nada se opone, ya que la magia está en vuestras manos [...] los muros se hienden, se vuelven del revés; del abismo parece que brota un gran teatro iluminado por un resplandor misterioso [...] que mediante las palabras mágicas sea ligada la razón; y, en cambio, la fantasía, vagabunda y soberbia, levante el vuelo; ahora, añade dirigiéndose a Fausto, contemplad con vuestros ojos lo que ambicionabais temerario; es un imposible y, por lo tanto, fidedigno (Fausto, 266).

Luego, el Astrólogo describe con palabras — literarias, es decir, "mágicas"- lo que los presentes observan: el desfile de espíritus que cruza

\footnotetext{
${ }^{14}$ En términos sucintos considero la parodia como el procedimiento mediante el cual se reproduce (escénicamente en este caso) una "representación" anterior, a menudo espejeando y deformando la realidad.
} 
el salón. Otras secuencias semejantes se insertan en el poema dramático de Goethe cual "episodios autónomos", cada uno con su propia dinámica representacional. Y, como hace todo teatro dentro del teatro, ${ }^{15}$ abren dentro del escenario una nueva dimensión ficcional, convirtiendo temporalmente a los propios actores en espectadores "de primera fila" - ya que los de "segunda fila" seríamos nosotros: los espectadores en la sala del teatro- . Equivalente a este recurso teatral sería, en la novela de Mann, la inserción de largas sesiones dialogadas que, como segmentos relativamente independientes, presenta Zeitblom en mitad de su narración, creando una especie de ventana que se abre desde la ficción novelesca hacia la realidad circundante del propio autor. ${ }^{16}$ En estos episodios Leverkühn participa con cierta distancia irónica, como un observador incrédulo. Se trata de auténticas "puestas en escena" de las ideas y debates ideológicos de la época, donde lo diabólico se disfraza de mera frivolidad con tintes sarcásticos. La función de "ventana hacia la realidad" que tienen estas conversaciones es análoga a la de una escena de teatro dentro del teatro, pues la burbuja de ficción inserta en el conjunto narrativo muestra la realidad "externa" de manera especular o "invertida". Es claro que este recurso especular es una de las estrategias de que se vale Mann para enlazar los dos niveles de su novela: la historia personal - ficticia - del compositor Leverkühn, y el clima político, cultural y social — real— de Alemania. El autor presenta el primer nivel de ficción como metáfora o parodia del segundo, y hace de Adrián Leverkühn un actor que en el escenario novelesco personifica al “espíritu alemán” y al propio destino de Europa. Aun más meta-teatral resulta la meticulosa descripción que hace Zeitblom de las composiciones musicales del protagonista para que el lector pueda "oírlas"

${ }^{15}$ El teatro dentro del teatro, al instaurar una especie de burbuja escénica en un escenario mayor, "duplicando" el efecto especular, no sólo revela — parodiándolo- el carácter ficticio de lo que ocurre en ese escenario mayor, sino que afirma el carácter verídico de lo que la "burbuja" muestra ( $c f r$. Ubersfeld, L'école du spectateur, 111-113).

${ }^{16}$ Por ejemplo, el episodio donde los jóvenes condiscípulos de Adrián (miembros de la Asociación de Estudiantes Cristianos de Winfried) discuten de religión, sociología, política ( $c f r$. 140-153), o la conversación entre intelectuales fascistas en la casa de Kridwiss (cfr. 440-452). 
virtualmente. ${ }^{17}$ Éstas no se refieren sólo a los aspectos técnicos y formales de las obras, sino a los sucesivos climas emocionales y a la dinámica dramática que en ellas se va desplegando, incluso en términos performativos; es decir, respecto del modo en que las obras fueron ejecutadas y recibidas por el público que asistió a los conciertos. ${ }^{18}$ Las composiciones de Leverkühn, descritas como auténticos eventos escénicos, actúan a manera de espejo o de metáfora musical de lo que sucede al nivel global de la novela: el desarrollo "agónico" de la vida interior del personaje, paralelo al derrumbe espiritual y social del entorno que vive de Zeitblom. El narrador se convierte así en el intermediario entre el novelista real y el compositor ficticio y, como una especie de director teatral, "pone en escena" con palabras aquello que los lectores tendríamos que escuchar "en presencia", inmersos en la atmósfera ominosa que su escritura va creando. También Leverkühn monta su propia escena: la de su confesión final, donde convierte a otros personajes en auditores involuntarios de su desgracia personal y de sus supuestos crímenes, haciendo de su vida un espectáculo a la vez ridículo y lúgubre (597-612). ${ }^{19}$ Pero sobre todo, este nuevo Fausto compone "escenificaciones sonoras" de sus luchas internas. Su poder diabólico es el de crear música: arte mágico que transforma las leyes naturales del sonido para crear mundos ficticios desde su "laboratorio" de artista, como un oficiante alquímico: "Yo, dice, ennoblecería la prima materia aportando la añadidura del magisterio y depurándola por el espíritu del fuego" (159).

${ }^{17}$ Por ejemplo, la del Oratorio cum figuris (sobre el Apocalipsis y la destrucción del mundo) (cfr. Doctor Faustus, 454-460), la de sus lieder (cfr. 223-224) o la de El Lamento del Doctor Fausto (cfr. 591 y ss.).

${ }^{18}$ Véase lo que dice Zeitblom cuando describe, por ejemplo. el Oratorio cum figuris: "Ahora bien, quien tenga oídos para escuchar y ojos para ver reconocerá en la trama musical de aquel trozo cuya magia ha conquistado, emocionado, trasportado hasta a los más refractarios, la risa del Diablo" (Doctor Faustus, 460).

${ }^{19}$ Adrián habla en alemán antiguo (como poseído por la voz del legendario Fausto): "sepan ustedes que desde mis veinte años estoy casado con Satán [...] y todo lo que en un término de veinticuatro años he realizado [...] es obra del diablo" (Doctor Faustus, 603). 


\section{Alquimia y "magia teatral"}

Desde su laboratorio de sabio, ya en los orígenes de la leyenda, el Doctor Johann Fausten, desencantado de las posibilidades del saber teológico, filosófico, científico - y en general, libresco- y ansioso por adquirir un conocimiento empírico, busca respuesta en la alquimia, disciplina que en el siglo XVI se encontraba a caballo entre la magia y la ciencia, y atentaba, como éstas, contra la autoridad del dogma religioso. Ya que lo sagrado no se digna revelarse a plenitud y que los designios de la naturaleza son inexpugnables, la magia se muestra como el último recurso del ambicioso sabio: "El gran espíritu me menospreció; la naturaleza se cierra ante mí. He roto el hilo de pensamiento y hace ya tiempo, mucho tiempo que me harta el estudio [...] Lancémonos a la borrachera del tiempo en el rodar de la contingencia", dice el Fausto de Goethe (Fausto, 113). "Un mago hábil es un semidiós", dice el de Marlowe, hablando consigo mismo. "Sé pues médico; amontona oro, y eternízate merced a una cura fabulosa" (La trágica historia ..., 48), para lograr incluso lo imposible: hacer regresar de la muerte a los hombres. "Sólo la magia me fascina" (50), remata un Fausto influenciado por la figura histórica de Paracelso y el legendario Simón el Mago. ${ }^{20}$

La magia, técnica de los signos y las sustancias, responde al afán de gobernar lo inerme, lo orgánico, lo anímico y lo sagrado, como si todo ello fuera parte de un mecanismo susceptible de ser dirigido por el hombre; en este sentido es que las artes de la nigromancia son un desafío a Dios, a la exclusividad de su función creadora y rectora. Recurrir a la magia implica un intento desesperado de controlar la naturaleza y de manipular incluso los designios de la divinidad, básicamente desde el ámbito de la "representación". Ello conlleva un peligro y una temeridad asociados a lo diabólico y a la herejía en tiempos de Fausto; pero incluso, hoy día, en términos seculares, implica una hybris digna de castigo, y en última instancia de conmiseración. ${ }^{21}$

${ }^{20}$ Simón de Gitta: líder religioso, astrónomo y gnóstico, mencionado en la literatura cristiana primitiva.

${ }^{21}$ Mircea Eliade señala que el afán tecnólogico (herencia de la alquimia) ha llevado al hombre a pervertir los procesos de la naturaleza, en aras de su control (cfr. Herreros $y$ alquimistas, 115-118). 
En tiempos más optimistas, Goethe, quien de hecho considera lo demoníaco como impulso para la evolución y el progreso, opta por integrar en su Fausto el sentido diabólico de la magia y el sentido angélico del arte, haciendo que el Mal se encauce en la acción creadora. Como dije antes, el poeta piensa que para librarse de lo demoníaco es necesario generar imágenes vivas que encarnen su misterio aterrador. Y para ello quizá, para exorcizar los oscuros poderes que intuye en sí mismo como artista, escribe su propia versión del mito fáustico: evocación de figuras míticas y fantasmas, no como "entes de palabras", sino como voces y cuerpos que "habitan" su poema. Sin embargo, y pues admite que el valor positivo de seguir al daimon puede degradarse, muestra a su Mefistófeles como un simple prestigiador, y a Fausto como su comparsa. Por razones casi contrarias, en la novela de Mann lo diabólico viene a ser el último recurso del genio que siente su creatividad amenazada: "El arte se ha vuelto impracticable sin la ayuda de Satán", dice Leverkühn (Doctor Faustus, 606), ${ }^{22}$ pues sólo él tiene el poder de desencadenar las fuerzas necesarias para crear. Leverkühn sufre respecto de su infertilidad creativa la misma desesperación que sentían el viejo Fausto de Marlowe y el de Goethe ante la imposibilidad de conocer y controlar las leyes del Cosmos $-\mathrm{y}$ escondido tras dicha frustración, el oscuro deseo de gloria - De ahí la opción por la magia, a la que claramente identifica Leverkühn con su labor de compositor, en una carta dirigida a su profesor de música, Kretzschmar:

La música me ha producido siempre el efecto de una combinación mágica de la Teología y de las tan amenas Matemáticas. Es más, se aproxima mucho al trabajo y las investigaciones de los alquimistas y nigrománticos de antaño, puestos igualmente bajo el signo de la Teología; pero también de la emancipación y la apostasía dentro de la fe (Doctor Faustus, 159).

Además de una coincidente vocación apóstata, lo que une la creatividad artística de este nuevo Fausto y el anhelo de sabiduría del antiguo

${ }^{22}$ La idea de escribir Doctor Faustus, asegura Mann en una carta de 1950, le vino al observar la crisis del arte de su tiempo, y cómo los artistas buscaban liberarse a toda costa de la paralipsis e inhibiciones intelectuales. 
son, pues, dos aspectos básicos: la "salida" por conducto de la magia, entendida como exploración directa sobre la materia, y el ejercicio de la magia como técnica "representacional". Concebida así, como técnica de signos en el tiempo (hechizos verbales, gestos, ritos, elíxires, visiones), con el supuesto poder para modificar fácticamente aquello que esos signos representan, la magia está ligada en el mito fáustico a las artes performativas (es decir, las que dan forma y transforman), y en especial al arte teatral, tanto en sus efectos como en sus procedimientos. ${ }^{23}$ Particularmente la alquimia, en su búsqueda de producir oro o de crear la medicina universal, más que una tecnología pre-química constituía una auténtica "dramaturgia de la materia" —explica el antropólogo Mircea Eliade en su libro Herreros y alquimistas - , que reproducía a nivel simbólico y psicológico la vida dramática de las sustancias. Su finalidad iba más allá de perfeccionar la materia misma: pretendía hacer renacer el alma del propio alquimista. Crucial en el arte del alquimista era la aceleración del tiempo natural para que metales como el cobre germinaran - fuera del vientre de la tierra - y crecieran "velozmente" hasta volverse "oro". En el laboratorio alquímico el fuego hace las veces del tiempo, apresurando el desenvolvimiento interno de las sustancias, de los cuerpos, del universo. También en el teatro, mediante "el calor" de una energía corporal y psíquica intensificada — esa energía "extra cotidiana" a la que se refiere Eugenio Barba como propia del arte escénico (Más allá de las islas flotantes, 107-108)—, el tiempo se condensa y varios paisajes convergen en el aqui y ahora de una escena, exponenciando su significación. Para un "poeta" del escenario, como Antonin Artaud, el teatro debe ser precisamente una especie de laboratorio alquímico y no un simple espejo de la realidad; un espacio de experimentación en el que, mediante el trabajo con el cuerpo y la materia, las pasiones se transformen para purificar a actores y a espectadores: un crisol de renacimiento. Es a partir de la dramaturgia de los signos (palabras, gestos o escritura musical) que Fausto invoca y trae a su presente al Diablo, tanto en El libro popular como en la pieza de

${ }^{23}$ Invocar a los espíritus y a los muertos, revelar lo oculto, modificar la función y apariencia de los objetos, trastornar las leyes físicas, comprimir el tiempo y el espacio, y en fin, generar todo un mundo alterno artificial, ya sea para consolar al alma, aliviar al cuerpo o abrir los ojos de la conciencia. 
Marlowe; tanto en El drama de titeres como en el poema dramático de Goethe, y en la novela de Mann. Sus artes mágicas, desencadenadas por el Diablo, se confirman como técnica de invocación, de materialización de espectros y modelaje de la materia, creando situaciones e imágenes "vivas" - aunque ficticias - que permiten una experiencia vivencial, como en un teatro secreto o un laboratorio esotérico. Si tomamos en cuenta que la "magia teatral" implica también una "herética" suplantación del mundo real, puede decirse que Fausto es mago en la misma medida en que es director de escena y actor de una trama. Desde las raíces del mito fáustico, la magia diabólica es, pues, representacional, escénica, performativa. En un ámbito teatralizado los sucesos se vuelven pauta de experimentación virtual y el saber es sólo el de la vivencia. Eso es lo que desea el sabio y desafiante Fausto de Marlowe, así como el esforzado y eufórico Fausto de Goethe: ser sujeto de toda la experiencia humana. Y para ello Mefistófeles, cuyo elemento esencial es el fuego, pone a su servicio los poderes portentosos de la ficción. El recurso básico del Diablo es manipular el tiempo, desgajándolo o concentrándolo en un presente absoluto, a fin de convertir el mundo en un escenario teatral —en el que veinticuatro años (periodo de vigencia del pacto) son las veinticuatro horas de un día, o las dos horas y media de una representación.

Curiosamente, y a diferencia de las versiones fáusticas anteriores, en el Doctor Faustus la magia performativa del Diablo no es fogosa sino gélida. Afín a la compleja escritura novelesca del propio Mann, el método de composición musical de Leverkühn - constructivo, programático, dodecafónico, atonal- despliega una técnica demoníaca "fría" para modelar lo espiritual a partir del material sonoro. Se trata de un "trabajo" creativo en el que la abstracción reina sobre la pasión, en el que la extrema intelectualización, que Marlowe y Goethe rechazaban, se impone sobre la ebullición caótica de las emociones, con el peligro de sofocar todo aliento vital, todo impulso amoroso, toda esperanza. Por eso Adrián Leverkühn habla de sí mismo como "asceta del Diablo" (Doctor Faustus, 608). En el ámbito de la composición musical, aquella vehemencia creadora, especie de "manía platónica" que lanzaba al artista ilustrado y al romántico en manos de lo demoníaco, es ahora una manía racional de muerte, que no puede sino desembocar en un monu- 
mental lamento: la pieza final de Leverkühn. Gracias a este personaje, el mito fáustico parece hacer el camino de regreso al punto del que había salido el Fausto original, que en el anhelo de los goces de la carne y la expansión del corazón fue capaz de comprometer su alma a fin de huir de la frialdad racional y de la muerte.

En todas las versiones del mito, la venta del alma al Diablo implica una renuncia al amor. A cambio, el Diablo ofrece el más tentador de sus "espectáculos", el de la belleza, personificada en la legendaria Helena de Troya. Ante su aparición Fausto pierde toda calma y objetividad, toda posible "frialdad" o distancia contemplativa, y cae en delirio enamorado. El Mefistófeles de Goethe regaña entonces a su "discípulo": “¡Domínate y limítate a tu papel!”(Fausto, 269), le dice, recordándole que la magia es sólo capaz de brindar un mundo de apariencias. El Demonio crea para Fausto visiones efímeras que al final no logran satisfacer su anhelo de conocimiento y trascendencia; fantasmas que, como la propia figura de Helena, terminan desvaneciéndose, lo mismo que se esfuman los espejismos que invoca el propio Fausto ante reyes, duques, cortesanos y estudiantes.

$\mathrm{Y}$ es que pese a todas sus artes ilusionistas y poderes sobrenaturales, el Diablo no puede suplantar lo real, ni puede hacer surgir una creación auténtica, alternativa a la de Dios. Sólo proporciona "falsas" realidades. Su poder es artimaña, simulacro del verdadero oficio divino de crear, aunque sus visiones ciertamente irrumpan en el mundo - como las de una ficción teatral-. En la suplantación de la experiencia, la "magia teatral" del Diablo es eficaz y peligrosa, puesto que seduce a la razón y excita a la imaginación, pero su ámbito de ejercicio es un mundo artificial, en el que la propia presencia demoníaca es una farsa.

En ese sentido mi padre tenía razón: tras su máscara, el Diablo no existe pero juega —o finge- que sí. Y esta ficción (la palabra ficción viene de fingimiento: de esculpir con los dedos) es producto de su mano izquierda, contraria a la realidad modelada por la diestra del Padre. La creación siniestra del diablo se equipara a la del arte, la alquimia y la ciencia, y se asocia a la imaginación, fuente de toda confusión y fantasmagoría.

De entre todas las criaturas fantasmagóricas generadas por el Diablo, la más impactante - lograda apenas en los albores de la modernidad- 
es sin duda el Yo del hombre, esa magna ilusión, non plus ultra de todos los espectros: especie de homúnculo interior que rige supuestamente la voluntad del individuo y busca hacer realidad los sueños de la razón. La razón del hombre, parapetada en el Yo, sueña con dominar a sus semejantes y suplantar el poder divino; para ello se esfuerza en conocer los secretos de la naturaleza, controlar y trastocar sus leyes. ¡Ah, cómo sueña la razón con esa libertad frente a su Creador! ¡Cómo sueña la temeraria inteligencia de Fausto el Nigromante! No es de extrañar que recurra a la magia ni que la leyenda fáustica del siglo Xvi se valiera precisamente de la figura del Diablo para "simbolizar" el reto a Dios por parte de toda "ciencia" nueva. Para el autor del antiguo Libro popular del Doctor Faustus, el luterano Johann Spies, no sólo la magia, la alquimia y la medicina, sino la ciencia en general, eran terrenos diabólicos.

\section{Libertad o sujeción}

En la pieza de Marlowe, el desafío diabólico a Dios por parte de la razón humana adquiere un signo positivo. El pacto con lo demoníaco pasa a representar la libertad de pensamiento de Fausto y sus legítimas ansias de conocimiento. Tres siglos después, y pese a sus prolíficas reflexiones sobre lo demoníaco como fuerza creativa, para Goethe el personaje de Mefistófeles no representa en realidad al daimon sino a un ser maligno degradado: no sólo carece del poder suficiente para llevarse a Fausto al infierno; ni siquiera es una auténtica representación de mal, sino sólo su caricatura. El auténtico daimon, portador de la genialidad que concebía Goethe reaparece, sí, en la figura del Diablo que convoca la novela de Mann. Ya sea que Fausto resulte o no condenado al final - es decir, para bien o para mal - pareciera que el Diablo es un verdadero agente de la libertad y de la rebeldía del hombre. Pero Fausto, al firmar el pacto con Satán, renuncia a esa libertad y se convierte paradójicamente en un títere en manos de Mefistófeles - con la anuencia de Dios, hay que decirlo-. Y puesto que Mefistófeles tampoco actúa "por cuenta propia", pues sólo es un enviado, resulta ser también un títere de su Señor, Lucifer. El famoso "libre albedrío", gran don de Dios otorgado al hombre, no es sino la coartada y ocasión (pues, ¿cómo podría actuar 
"El Tentador" si no existiese tal pretendida libertad?) para que ambos, Fausto y Mefistófeles, se conviertan en juguetes del Destino, personajes de una mascarada. Hay que recordar que en el Fausto de Goethe la acción dramática "se abre" con una escena metafísica, base del conflicto entre el Bien y el Mal que vivirá el protagonista. Se trata del "Prólogo en el cielo" (75-78), donde Dios hace una apuesta con el Diablo respecto de la integridad moral de su siervo, Fausto. Mefistófeles, por su parte, asegura ser capaz de desviar el camino del sabio y provocar la condenación de su alma:

MEFISTÓFELES: ¿Qué apostamos? Si me permitís atraerlo paulatinamente a mi camino, también le perderéis a él. [...]

EL SEÑOR: Pues, bien, jte lo entrego! Aparta a ese espíritu de su manantial y arrástrale, si puedes con él, por tu pendiente; pero avergüénzate si tienes que reconocer que un hombre bueno, en lo oscuro de su impulso, tiende hacia el camino recto" (77). ${ }^{24}$

La triste parodia sobre la libertad que se despliega a partir de esta apuesta inicial coloca a Fausto y a Mefistófeles en un supuesto antagonismo, que sin embargo se contradice en el fondo. Una vez "autorizado por Dios", el Diablo en la novela de Mann actúa en efecto como "el corruptor", pervirtiendo los legítimos anhelos artísticos de Leverkühn (que no son la fama, ni el poder mundano sino una gloria aún más perversa: la solitaria grandeza del arte); el Mefistófeles de Goethe desvirtúa —niega - los sanos impulsos de acción (esfuerzo y el trabajo) de Fausto, que supuestamente debe "aguijonear", así como su osado deseo de vivir "toda la experiencia humana", sumergiéndolo en el terreno de lo ilusorio; y el de Marlowe enturbia la búsqueda de lucidez, placer y vitalidad del sabio Nigromante. La misión diabólica es hacer que los anhelos fáusticos se disparen hacia lo imposible, con toda la soberbia y patetismo que esto implica, para preparar así su caída. Desde esta perspectiva, el Diablo es realmente el enemigo del hombre, pero es también el ánimo, la fuerza oculta que actúa dentro de él. En sus Conversaciones

${ }^{24}$ Dios "utiliza" a Fausto para demostrar la supremacía del bien en la actuación de sus creaturas, tal y como puso a prueba la fidelidad de Job. En ese sentido, la leyenda fáustica es "descendiente" del Libro de Job bíblico. 
con Goethe, Eckermann cita estas palabras del poeta: "Lo demoníaco es aquello que no puede explicarse por el intelecto ni por la razón. Yo no noto en mí ese elemento; pero sí noto que le estoy sometido" (apud González García, Las huellas de Fausto, 159). ${ }^{25}$ Es por eso que algunos críticos aseguran que en el mito fáustico lo demoníaco aparece como preludio del inconsciente, del Ello, concebido en las teorías de Freud. En todo caso, diría yo, se trata de un Ello (instinto y voluntad de sentir) que se alía con el super-ego (razón y voluntad de poder) y adquiere así mayor peligrosidad. El Yo se convierte en el campo de batalla entre las fuerzas del querer y del deber, y es finalmente la instancia condenada.

Los tres autores reconocen la actuación de lo demoníaco en sí mismos y se identifican con el Fausto mítico y sus ansias de imposible: Marlowe encuentra en el Fausto legendario una especie de alter-ego, no sólo en cuanto a la rebeldía de pensamiento y heterodoxia de aquel personaje "vendido al Diablo", sino también porque el dramaturgo era, además de libertino, sensual y aventurero, un simulador: trabajaba como espía de los servicios secretos al mando del jefe de policía, durante la persecución contra los católicos, siendo en realidad un doble agente contrarreformista. Goethe, por su parte, cuenta en Poesía y verdad cómo la figura de Fausto (que conoció por primera vez en un teatro de títeres en Estrasburgo) le había impactado: "también yo [como Fausto] había vagado por toda clase de sabiduría y bastante temprano había comprendido la vanidad de ella. También yo había intentado lo mismo en la vida de muchas maneras, y siempre había regresado más insatisfecho y atormentado" (apud Oeste de Bopp, "Prólogo", El libro popular..., 21). En Los orígenes del Doctor Faustus, Mann expresa también su identificación con el personaje: "Los discursos de Adrián, dice, me llegaban tan profundamente al alma, como me habían salido de ella" (160). Así pues, los tres autores hacen de sus respectivas versiones del mito una especie de confesión - y enmascarada apología - de su propio quehacer creativo: soberbio, herético y en cierto punto demencial. La obra de

${ }^{25}$ Refiriéndose a la genialidad, Goethe asegura que "viene a ser algo parecido a ese elemento demoníaco [o daimon] que se apodera [del hombre] a su capricho y al que el hombre se entrega inconscientemente, creyendo seguir su propio impulso. En estos casos debe considerarse al hombre más como un instrumento" (citado por González García, Las huellas de Fausto, 159). El daimon, pues, "maneja los hilos de nuestra vida". 
cada uno representa un meticuloso y desgarrado examen de conciencia, como el que expone Adrián Leverkühn al final de la novela; como el que se despliega en la desesperada conversación que escribe Goethe entre "La preocupación" y Fausto, cuando está a punto de condenarse; y como el discurrir arrepentido que en su última hora hace el protagonista de Marlowe. El Yo fáustico, pese a reconocer su error trágico (su "fatal" elección) no puede perdonarse ni pedir clemencia al Diablo o a Dios. Consciente -o perversamente orgulloso - de la dimensión metafísica de su "crimen", termina por condenarse a sí mismo. "Mi pecado es demasiado grande para serme perdonado, confiesa Leverkühn, y yo lo he llevado al extremo $[\ldots]$ condenado estoy y no hay misericordia para mí, porque yo la destruyo de antemano con mi especulación" (Doctor Faustus, 611).

Ya en el antiguo Drama de títeres, durante la escena final, el protagonista se decía a sí mismo: "Ahora, Fausto, estás condenado a causa de tus pecados. Oigo anunciar con terror, castigo y muerte para mí. Muy bien, venid entonces, furias del infierno. Y llevaos el alma, condenada desde hace mucho" (El libro popular..., 240). Contra esta predestinación eterna, de perverso modo predestinada, se debate la conciencia de Fausto en la pieza de Marlowe:

Dios, si no quieres apiadarte de mi alma [...] impón al menos algún fin a mi dolor ilimitado [...] Mas no existe fin para las almas condenadas. ¿Por qué no habrás carecido de alma, criatura? ¿Por qué la tuya es inmortal? [...] ¡Malditos sean los que me engendraron! No, Fausto, maldícete a ti mismo o maldice a Lucifer que te ha privado del júbilo del cielo" ( $\mathrm{La}$ trágica historia..., 123-124).

Esta condenación eterna "permitida" por Dios — quien además impide a las almas dejar de existir - pasa a ser responsabilidad del propio Fausto; y Mefistófeles, igualmente digno de compasión, no hace sino hacerla efectiva con sus artes malignas, por mandato de Satán.

Como figuras a expensas de su creador, sobrenatural o humano, tanto el personaje de Fausto como el personaje de Mefistófeles, pese a actuar como antagonistas y pese al uso de su "libre arbitrio", tienen en común el hecho de ser marionetas de una voluntad superior y ajena. 
Comparten, además, un mismo Destino: la caída de la Gracia divina y la expulsión eterna del Paraíso Celestial. Es evidente que el mito fáustico representa en el escenario del mundo, la soberbia, la rebeldía y la caída del ángel Luzbel. Fausto remeda en la dimensión humana, histórica, el drama vivido illo tempore por Lucifer, quien después de haber sido un ángel "bienamado de Dios" fue expulsado de la faz de los cielos. “№ comprendes que para mí, que vi el rostro de Dios y saboreé el regocijo eterno de los cielos, el verme privado de esa exaltación perpetua es un tormento peor que mil infiernos?" (La trágica historia..., 55), dice el Mefistófeles de Marlowe, cuando Fausto le pregunta cómo es que puede estar afuera del Infierno y presentarse ante él. "Oh, no estoy fuera, esto es el infierno" (55), le había respondido el Diablo, refiriéndose a la mismísima realidad como lugar de exilio y tormento. La turbia atmósfera política en que vivía Marlowe, justifica esta declaración de Mefistófeles. Asimismo, la realidad política y cultural en tiempos de Mann se había vuelto "demoníaca" y convertía la historia de Europa en una mascarada siniestra. Y es que Lucifer ha enviado a Mefistófeles a montar, en el mundo terrenal, la puesta en escena de aquella su caída. Para ello el representante del Maligno cuenta con los poderes de la mistificación y de la ficción, así como con la fantasía del hombre y su Yo infatuado - infatuación que va desde el extremo individualismo del Fausto de Marlowe, hasta el ascetismo intelectualista de Leverkühn, pasando por el temerario "optimismo" del Fausto goetheano, quien sin embargo en cierto momento exclama: ¡Maldito sea todo lo que engendra una alta opinión de sí mismo de que rodea el espíritu! ¡Maldito el brillo de la apariencia que deslumbra nuestros sentidos! ¡Malditos los sueños hipócritas que nos enseñaron con engaños la fama y la perduración de nuestro nombre!" (Fausto, 109-110).

Pero la "actuación" más astuta del enviado diabólico es sin duda la de mostrarse como doble del propio Fausto, reflejo pervertido de su Yo. El rostro de Mefistófeles genera un espejo en el que Fausto mira su propio rostro - un espejo cambiante, de muchas máscaras-, que representa el desdoblamiento continuo de ese "espíritu de imposible" que anima al mítico Nigromante. En la novela de Mann, además de prefigurarse en otros personajes "El Impostor" aparece como alter ego o proyección delirante de Leverkühn y le lleva a enredarse en lo que Zeitblom califica 
de un "esgrima ante el espejo" (Doctor Faustus, 270). En el poema de Goethe, además de disfrazarse y en cierto momento suplantar a Fausto ante otros personajes, Mefistófeles funge como representante "caricaturesco" del daimon oculto en el interior del protagonista, e incluso del propio autor, Goethe, quien confiesa llevarle siempre consigo como una sombra. El Diablo que concibe Mann, refiriéndose a su capacidad de metamorfosis, dice a Leverkühn: "Pero en esta adaptación [disfraz que adopto ahora] "¿no verás una alusión a tu persona, y no me tendrás inquina por ello?" (279). Finalmente, el Mefistófeles de Marlowe, comprendiendo las tribulaciones de Fausto por haber sido él mismo una víctima del conflicto entre Dios y Lucifer, expresa como propia la tragedia del protagonista. Fausto y Mefistófeles son "emanaciones del mismo sujeto", dice el crítico Marcelo Cohen ("Introducción", $L a$ trágica historia..., 34), personificaciones de dos fuerzas confrontadas en una misma conciencia: "Infierno y gracia luchan por conquistar mi pecho" confiesa el Fausto de Marlowe (La trágica historia ..., 115). Y es esta lucha, drama interior del sujeto desdoblado, la que se "exterioriza" y materializa en la escena fáustica, en la que fuerzas opuestas encarnan. ¿Pero qué fuerzas son las que personifican Fausto y Mefistófeles, su "doble"? No son simplemente las del Bien y el Mal, como tendencias diferenciadas y antagónicas de la conciencia; lo que confronta a Fausto y a Mefistófeles es una diferencia ontológica. Fausto, hombre mortal, está sometido al tiempo; el Diablo, espíritu inmortal, cuenta en cambio con el tiempo, con todo el tiempo que existe, pues lo pagó con su propia condenación: “...tenemos tiempo, largo tiempo, incalculable. El tiempo es lo mejor y lo más esencial de lo que concedemos nosotros", dice el Demonio en la novela de Mann (Doctor Faustus, 277). El encuentro entre seres ontológicamente distintos no puede expresarse sino en un terreno fantasmagórico, especular. Es precisamente el tiempo (un presente condensado y total) lo que Mefistófeles ofrece a Fausto a cambio de su alma (instancia "fatalmente" inmortal). Y el cuerpo de Fausto es "el terreno de lucha" en el que el conflicto entre el Bien y el Mal metafísicos (míticos) se conjugan con el Bien y el Mal éticos (históricos). Pero es también ahi, en "el pecho" de Fausto, donde bulle este otro conflicto más profundo asociado a la temporalidad: el conflicto entre la condición mortal de un hombre que anhela la inmortalidad y la condi- 
ción inmortal de su alma, que no puede sustraerse a la eternidad en caso de condenación. Mientras Fausto siga vivo —es decir, en posesión y custodia de su alma - la única manera con la que cuenta Mefistófeles para fundir la dimensión metafísica del infierno con la dimensión ética del libre albedrío —o la predestinación — es la ficción teatral. Es éste el campo de acción de la "alquimia diabólica", donde el tiempo mítico y el histórico se funden en un presente vivencial, si bien paradójico y en tensión.

Pese a ser "juguete" de los poderes sobrenaturales, el hombre podría soslayar la fatal apuesta por medio de la muerte. Pero ya que Mefistófeles, representación del Diablo en la dimensión humana, no puede salir del mundo de las apariencias qué el mismo ha montado, Fausto, como ente ficcional, tampoco encuentra salida en un suicidio que el enviado diabólico le impide. La tragedia de Fausto es, pues, la del hombre que queda "encerrado" con su Demonio dentro del mundo, cuando este mundo, ya convertido en ilusión transitoria, pasa a ser un infierno eterno. "La ofensa de Fausto no puede perdonarse... [dice el auto-inclemente Fausto de Marlowe] y debo ser confinado en el tiempo para siempre" (La trágica historia ..., 119). De manera análoga, la condenación de Leverkühn es un infierno "en vida": la demencia. Y así, el infierno al que se refiere Mefistófeles es verdaderamente "esto": la realidad que circunda a Fausto. "El infierno está donde estamos nosotros y nosotros vivimos para siempre donde esté el infierno", le dice (La trágica historia..., 62). Cierto es que para aquellos mortales que anhelan con vehemencia la inmortalidad, un mundo sin muerte se convertiría paradójicamente en un infierno, en el que dichas y desgracias retornan sin cesar. ${ }^{26} \mathrm{El}$ mundo real queda entonces reducido a un "Teatro del mundo" orquestado por el Diablo, sin escapatoria a ninguna otra "realidad" externa, liberadora; un teatro macabro donde, sin embargo, y a diferencia de la ficción, sí morimos y el tiempo jamás se detiene ni regresa. En la doble imposibilidad de vencer a la muerte del cuerpo y a la inmortalidad del alma radica el núcleo mítico de la tragedia fáustica que, incluso

${ }^{26}$ Como sucede precisamente en la ficción teatral, donde el acontecer se vuelve recurrente, pues el tiempo lineal de la fábula se vierte en el tiempo concéntrico de la escenificación ( $c f r$. Carmen Leñero, "Palabra poética y teatralidad", en La escena invisible, 21-32). 
si ocurre sólo en el ámbito más íntimo de la psique, no puede mostrarse o experimentarse a cabalidad en el relato, y precisa por ello de la dimensión teatral, es decir, de un ámbito ficcional organizado en torno al eje del antagonismo, de fuerzas en un conflicto sin solución posible.

Quizá para evitar estas fantasmagorías y angustias en mi conciencia infantil es que mi padre insistía en que el Diablo no existe. Y admito que su argumento tenía un lado fuerte, pragmático: "Si no creo en el Diablo, entonces no se me hará presente", tendría que pensar yo - acorde a lo que expresa Zeitblom bromeando: "Quien cree en el Diablo ya le pertenece" (Doctor Faustus, 228) —. Y en todo caso, su eventual aparición sería solamente el producto de un desacomodo de mis sentidos o de las contradicciones de mi mente, y no una verdadera irrupción en mi realidad cotidiana. Supongo que el propio Diablo estaría de acuerdo en aceptar dicha restricción fenoménica, pero según su costumbre, voltearía el argumento de manera astuta, como lo hace en la novela de Mann: "Si tú me ves, es porque existo para ti. ¿Vale la pena preguntar si yo existo realmente? Lo que ejerce una acción, ¿no es real, y la verdad no está en la aventura vivida y en el sentimiento?" (297). Contradictorio resulta que entre las enseñanzas de mi padre estuviera la práctica constante del autoexamen y la toma de responsabilidad no sólo ante mis actos sino ante mis más secretas intenciones, pues tal hábito implicaba una búsqueda casi detectivesca de la presencia del mal que habitaba dentro de mí, un estado continuo de vigilancia para descubrir las huellas de lo diabólico y sus posibles máscaras alrededor mío. Así que, por mucho que el Diablo no existiera, a menudo su actuación e influencia me causaban dolor, rabia, culpa y ese terror corrosivo que se siente frente "aquello" que no se digna aparecer nítidamente ante los ojos de la conciencia.

Fausto, nuestro Fausto, hermano en la desgracia, es aquel al que el Diablo sí se le parece, personificado, como experiencia definitiva, sensible, psicológica y espiritual - y no como mero concepto-. Un escenario teatral, ritual, es el sitio indicado para tal aparición "objetiva", corporeización del sentimiento de lo maligno, revelación de su latencia y acción disruptiva en la historia de uno. Dice Pirandello que el teatro es el espacio público en el que nuestros fantasmas privados - los más íntimos y furtivos - encarnan y se hacen visibles. Pero es también donde 
se "personifica" otra la escisión de la conciencia: la antinomia entre "ser y mirarse ser"; la del sujeto y su reflejo objetivado, como Fausto y su doble, Mefistófeles. El actor teatral, como reflejo vivo, revela el movimiento del hombre que se desdobla para ser a un tiempo personaje y espectador de sí mismo. Por eso, dice Pirandello, es necesario "fingir para ser", actuar para conocerse (Carmen Leñero, La luna en el pozo, 22). La vivencia de lo ético, más allá de lo ideológico y moral, pasa por esta auto-observación en cierto modo histriónica, egocéntrica y esquizoide.

En la raíz del mito fáustico yace, pues, una paradoja: tan pronto como el hombre desplaza a Dios del centro de su cosmovisión y se concibe como centro del mundo - un hombre renacentista ya sin "temor de Dios"-, ese individuo autosuficiente, integral, pretendidamente autónomo, se escinde: "En mí, ¡ay! anidan dos almas", dice el Fausto de Goethe (Fausto, 98). El antagonismo teatral entre Fausto y Mefistófeles revela, pues, el drama interior del sujeto escindido. Fungiendo como doble especular de Fausto (su daimon, su sombra, su reflejo macabro), Mefistófeles materializa la contradicción interna del personaje a nivel psicológico y a la vez personifica una dimensión inmortal de su ser: el alma caída en desgracia. Como personificación de todo desafío a Dios, al Bien, al Orden, el Diablo se identifica a veces con la razón y otras con lo instintivo y salvaje; a veces con la risa y el placer; o con la nostalgia del Paraíso y el desengaño incurable. La conciencia es el escenario interior que gracias al mito fáustico se vuelve visible, exterior, para mostrar vívidamente la realidad de esas "dos almas" que luchan en el corazón del hombre.

\section{Conclusión}

Tanto por la materialización objetiva del Mal (desdoblamiento de una conciencia escindida) en un personaje enmascarado, como por la actualización del antagonismo entre el Bien y el Mal, en una trama cuyo eje está conformado por tres "escenas" emblemáticas: la ceremonia inicial de invocación, la escena central del pacto y la de la condenación — con un desmembramiento corporal que remite al del alma-, considero que el núcleo del mito fáustico es en realidad un rito —el de 
comerciar "cara a cara" con el Mal, comprometiendo el alma, a partir de un contrato material, y en virtud de un gesto muy específico: la firma con sangre- Estos elementos rituales y el apersonamiento del Demonio están de alguna manera presentes en cualquiera que sea la forma de imaginación artística que recrea la historia de Fausto. Creo que el tema fáustico es intrínsecamente teatral, aunque su origen haya sido el conjunto de relatos recogidos en El libro popular..., y aunque haya sido objeto de variadas formulaciones literarias, musicales y pictóricas. En todas sus versiones (narrativas, filosóficas, dramatúrgicas, líricas) la historia de Fausto se remite a una imaginación que trabaja en una dimensión escénica interiorizada — es decir, una imaginación que se sitúa en un espacio material concreto, en un aquí, que funcionará como espacio simbólico-; una imaginación que compacta los diferentes tiempos en un presente, un ahora que retorna, simultáneo al del receptor, locutor o lector; una imaginación, en fin, que hace del cuerpo y su acción concreta sus signos centrales. Fausto es una figura legendaria que a lo largo de sus transmigraciones literarias se constituye en tipo (alter ego del filósofo, del artista, del escritor mismo): representación simbólica del hombre que, a partir del Renacimiento, se ve en una encrucijada ética necesariamente trágica, por cuanto que manifiesta una contradicción básica: es en virtud de su libre albedrío que el hombre se convierte en marioneta, ya sea del Diablo, de Dios o de sí mismo.

\section{REFERENCIAS}

El libro popular del doctor Faustus [1587], trad. y "Prólogo" Marianne oeste de Bopp, ed. Marcela Ruiz Lugo, México, Universidad Nacional Autónoma de México, 1984.

"El drama de títeres del doctor Faustus" [1912], en El libro popular del doctor Faustus, trad. Marianne oeste de Bopp, ed. Marcela Ruiz Lugo, México, Universidad Nacional Autónoma de México, 1984, 159-241.

BARBA, Eugenio, Más allá de las islas flotantes, México, Gaceta / Universidad Autónoma Metropolitana, 1986 (col. Escenología).

Bentley, Eric, La vida del drama, [1964], México, Paidós, 1985.

Eckermann, Conversaciones con Goethe [1902], en Goethe, Obras completas, vol. II, Madrid, Aguilar, 1963. 
Eliade, Mircea, Herreros y alquimistas [1956], Madrid, Alianza Editorial, 1983.

Goethe, von W. Johann, Fausto [1709], trad. y estudio preliminar J. M. Mínguez. (15-60), Barcelona, Bruguera, 1972.

González García, José M., Las huellas de Fausto: la herencia de Goethe en la sociología de Max Weber, Madrid, Tecnos, 1992.

LeÑero, Carmen, La luna en el pozo, ensayos sobre el arte teatral, México, Consejo Nacional para la Cultura y las Artes, 2000 (col. Sello Bermejo). LEÑERo, Carmen, La escena invisible. Teatralidad en textos filosóficos y literarios, México, Consejo Nacional para la Cultura y las Artes, 2009.

Mann, Thomas, Doctor Faustus [1947], trad. J. Farrán y Mayoral, Barcelona, Plaza y Janés, 1982.

Mann, Thomas, Los orígenes del doctor Faustus. La novela de una novela [1949], Madrid, Alianza Editorial, 1976.

Marlowe, Christopher, La trágica historia del doctor Fausto [1593], trad. e Introducción de Marcelo Cohen (7-39), Barcelona, Icaria, 1983.

Reuter, Jasmin, Fausto, el hombre. Tradición fáustica y situación fáustica, México, Universidad Nacional Autónoma de México, 1965 (col. Textos del Teatro de la Universidad de México).

Ubersfeld, Anne, L'école du spectateur, Paris, Éditions Sociales, 1981. 